
ЦЕНТРАЛЬНІ СИЛИ ПРОМИСЛОВОЇ БЕЗПЕКИ ЯК СУБ'ЄКТ
ЗАХИСТУ ОБ'ЄКТІВ КРИТИЧНОЇ ІНФРАСТРУКТУРИ ІНДІї

\title{
THE CENTRAL INDUSTRIAL SECURITY FORCES AS THE SUBJECT OF PROTECTION OF CRITICAL INFRASTRUCTURE FACILITIES OF INDIA
}

у статті обгрунтована актуальність теми дослідження, яка зумовлена недосконалістю системи захисту об'єктів критичної інсрраструктури України, актуалізацією загроз зазначеним об'єктам і реформуванням Національної гвардії України, що, у свою чергу, викликає необхідність у вивченні міжнародного досвіду у сорері захисту об'єктів критичної інфраструктури та здійсненні заходів із впровадження кращої практики у діяльність Національної гвардії України. Проведений аналіз останніх досліджень і публікацій вітчизняних та зарубіжних срахівців за напрямом дослідження. Висвітлене призначення Центральних Сил Промислової Безпеки. Наведені фуннкиї Центральних Сил Промислової Безпеки, основними з яких є: охорона об'єктів критичної інфраструктури, що перебувають у державній власності; охорона спеціальних вантажів під час їх перевезення; забезпечення пожежної безпеки об'єктів, що охороняються; участь у ліквідації наслідків виникнення надзвичайних ситуацій на об'єктах охорони; забезпечення безпеки посадових осіб, щодо яких здійснюється державна охорона; охорона державних установ (організацій), що розташовані на території інших країн; участь у миротворчих операціях, які проводяться під егідою Організації Об'єднаних Націй; охорона на договірних засадах об'єктів, які перебувають у приватній власності; надання консультаційних послуг організаціям різних форм власності 3 питань забезпечення безпеки та протипожежного захисту об'єктів. Встановлено, що до структури Центральних Сил Промислової Безпеки входять: Штаб-квартира, Резервні батальйони, Крило пожежної служби, Спеціальна група безпеки, Поліцейський підрозділ миротворчих місій Організації Об'єднаних Націй, Сектор підготовки, Сектор аеропортів і Регіональні Сектори. Визначені відмінності між діяльністю Центральних Сил Промислової Безпеки Індії та Національно гвардії України, основними з яких є: кількість об'єктів охорони, виконання специфрічних фунниій тощо. Надані рекомендації щодо використання отриманих результатів проведеного дослідження. Вказані подальші перспективи проведення досліджень за обраним напрямом.

Ключові слова: Центральні Сили Воєнізованої Поліції, Центральні Сили Промислово Безпеки, Національна гвардія України, націо- нальна безпека, критична інфрраструктура, об'єкm, захист.

The relevance of the research topic is substantiated in the article, which is conditioned by the imperfection of the existing critical infrastructure's facilities protection system of Ukraine, by the update of threats to specified facilities and by the ongoing reformation of the National Guard of Ukraine. This, in turn, causes the need for studying of the international experience in the sphere of critical infrastructure's facilities protection and taking actions for implementation of the best practice to the National Guard of Ukraine activity. The analysis of latter researches and publications of domestic and foreign specialists by the research direction is carried out. The appointment of Central Industrial Security Forces is elucidated. The functions of Central Industria Security Forces are given. The basic of them are: protection of critical infrastructure's facilities that are state-owned; protection of special cargoes during their transportation; providing the fire safety of facilities that are under protection; participation in liquidation of consequences of arising emergencies on facilities that are protected; providing the safety of officials, for which regarding the state protection is exercised; protection of government agencies (organizations) that located in the territory of other states; participation in peacekeeping operations that are conducted under the auspices of the United Nations protection on a contractual basis of privately owned facilities; providing consulting services to organizations of different property forms on ensuring protection and fire safety of facilities. It is established, that to the structure of the Central Industrial Security Forces are comprised next fundamental elements: Force Headquarters, Reserved Battalions, Fire Service Wing, Specia Security Group, Formed Police Unit of the UN, Training Sector, Airport Sector and Regional Sectors. The differences between the activity of the Central Industrial Security Forces of India and the National Guard of Ukraine are determined. The basic of them are: number of facilities that are under protection; performing of specific functions, etc. Recommendations of using received results of the conducted research are given. Further perspectives of conducting researches in the chosen direction are pointed.

Key words: Central Armed Police Forces, Central Industrial Security Forces, the National Guard of Ukraine, national security, critical infrastructure, facility, protection.
Постановка проблеми у загальному вигляді. Загострення соціально-політичної кризи в державі за умов ведення проти України гібридної війни, підвищення ймовірності скоєння на її території диверсійно-терористичних актів, знищення та руйнування численних об'єктів критичної інфраструктури (далі - KI) в зоні проведення Операції об'єднаних сил - все це визначає ті сучасні реа- лії, в яких сьогодні існує Україна, і в яких має забезпечуватися безпека її громадян, суспільства і держави [1, с. 168].

Саме сьогодні, за всю історію незалежності України, відбувається актуалізація загроз, пов'язаних 3 об'єктами КІ, в т. ч. й 3 атомними електричними станціями (далі - АEC). Так, на підґрунті скоєння спроби нападу на Запорізьку AEC у травні 2014 р. Урядом 
нашої держави був направлений у Міжнародне агентство з атомної енергії лист із попередженням про небезпеку об'єктам атомної інфраструктури України. Таким чином, від об'єктів КІ нашої держави, в умовах ситуації, яка склалася в окремих районах Донецької та Луганської областей, надходить перманентна загроза [2, с. 21].

Зазначене робить особливо актуальним для України удосконалення системи захисту об'єктів KI, яка активно розвивається у провідних країнах світу як один із сучасних шляхів реалізації державної політики у сфері забезпечення національної безпеки держави.

Одним із напрямів діяльності органів державного управління у сфері забезпечення безпеки об'єктів KІєвиконання заходів із їхзахисту.

Національна гвардія України (далі - НГУ) як один із суб'єктів захисту об'єктів КІ держави в межах своїх повноважень зобов'язана вивчати міжнародний досвід із захисту визначених об'єктів і здійснювати заходи щодо впровадження кращої практики під час виконання заходів із захисту об'єктів КІ [3; 4, с. 146].

Нині НГУ перебуває у стані активного реформування. Безумовно, для досягнення цілей реформ, що впроваджуються, необхідно вивчати досвід провідних країн світу, в т ч. у сфері захисту об'єктів КІ.

Отже, з урахуванням актуалізації загроз об'єктам КІ України та реформування НГУ обраний напрям дослідження набуває особливої актуальності.

Аналіз останніх досліджень і публікацій. Вагомий внесок у дослідження окремих аспектів реалізації державної політики у сфері захисту об'єктів КІ та особливостей діяльності правоохоронних органів провідних держав світу, в т. ч. щодо забезпечення безпеки визначених об'єктів, внесли такі науковці, як О.М. Суходоля [5], Е.Н. Ходатенко [6], В.О. Євсєєв [4] та ін.

Так, у статті [5] автор висвітлив проблеми та пріоритети державної політики України щодо захисту КІ в умовах ведення гібридної війни.

У роботі [6] розглядаються правові основи функціонування Цивільної Поліції Індії та її організаційно-управлінська структура.

У публікації [4] наведені призначення, структура й основні функції Поліції Великої Британії з охорони цивільних ядерних установок і матеріалів (Civil Nuclear Constabulary).

Виділення не вирішених раніше частин загальної проблеми. Дослідженню в галузі державного регулювання у сфері захисту об'єктів КІ та особливостей діяльності правоохоронних органів провідних держав світу щодо забезпечення безпеки даних об'єктів присвячена певна кількість публікацій вітчизняних і зарубіжних фахівців.

Проте нині поза увагою науковців залишається дослідження досвіду й особливостей діяльності правоохоронних органів Індії у сфері захисту об'єктів КІ, а саме Центральних Сил Промислової Безпеки (Central Industrial Security Forces, далі - CISF) як одного з найбільш потужних суб'єктів захисту визначених об'єктів у світі.

Мета статті - провести дослідження особливостей призначення, основних функцій, організаційно-штатної структури та досвіду діяльності CISF.

Виклад основного матеріалу. Центральні Сили Воєнізованої Поліції (Central Armed Police Forces, далі - CAPF) є правоохоронним воєнізованим органом, що входить до складу Міністерства внутрішніх справ Індії, та призначені для підтримки діяльності Уряду щодо забезпечення верховенства права, недоторканності кордонів, громадського порядку та внутрішньої безпеки держави [7].

До складу CAPF входить сім формувань, створених за основними специфічними напрямами діяльності. Одним із таких формувань $\epsilon$ CISF.

CISF були створені у 1969 р. з метою забезпечення безпеки об'єктів КІ, які в ті роки мали стратегічно важливе значення для економіки республіки Індія [8]. На момент утворення до складу CISF входило 3 батальйони загальною чисельністю близько 2800 осіб [8].

Згодом у зв'язку із глобалізацією та лібералізацією економіки Індії, бурхливим промисловим і науково-технічним розвитком держави, з урахуванням підвищення ймовірності скоєння на території республіки диверсійно-терористичних актів на тлі періодичного загострення давнього конфлікту з Пакистаном і Китайською Народною Республікою (Кашмірський конфлікт), виникла нагальна потреба у реформуванні CISF, яке полягало б у розширенні кола основних функцій, зміні організаційно-штатної структури формування та збільшенні чисельності особового складу зазначеного формування.

На цьому підґрунті у 1983 р. Уряд Індії прийняв рішення щодо розширення кола основних функцій CISF і збільшення чисельності формування до 148000 осіб. У наступні роки також неодноразово вносилися зміни у відповідні нормативно-правові акти, які переважно були спрямовані на доповнення переліку основних функцій CISF, зміни в організаційно-штатній структурі та подальше збільшення чисельності особового складу зазначеного формування. Нині до складу CISF входить близько 180000 осіб [9]. 
Отже, з урахування внесених змін до відповідних нормативно-правових актів Індії можна стверджувати, що CISF - правоохоронне воєнізоване формування у складі CAPF Міністерства внутрішніх справ Індії, призначене для охорони об'єктів KI держави будьякої форми власності, а також виконання інших функцій, що можуть бути покладені на нього Центральним Урядом.

Сьогодні одними з основних функцій CISF є [8-10]:

- охорона об'єктів KI, які перебувають у державній власності;

- охорона спеціальних вантажів під час іx перевезення;

- пожежна охорона об'єктів, що охороняються;

- участь у ліквідації наслідків виникнення надзвичайних ситуацій на об'єктах, які охороняються;

- забезпечення безпеки осіб, віднесених до категорій Z+, Z, X та Ү, перелік яких визначається Міністерством внутрішніх справ, за місцем їх перебування на території Індії;

- охорона державних установ (організацій), розташованих на території інших країн;

- участь у миротворчих операціях, що проводяться під егідою Організації Об'єднаних Націй;

- охорона на договірних засадах об'єктів, які перебувають у приватній власності;

- надання консультаційних послуг організаціям різних форм власності з питань забезпечення безпеки та протипожежного захисту об'єктів.

Очолює CISF Генеральний Директор. Головним органом управління CISF $€$ Штабквартира (Force Headquarters, далі - FHQ) [8].

У прямому підпорядкуванні $\mathrm{FHQ}$ перебувають Резервні батальйони (Reserved Battalions, далі - RBs), Крило пожежної служби (Fire Service Wing, далі-FSW), Спеціальна група безпеки (Special Security Group, далі - SSG), Поліцейський підрозділ миротворчих місій Організації Об'єднаних Націй (Formed Police Unit of the UN, далі - UN FPU) та Сектори, а саме: підготовки (Training Sector), аеропортів (Airport Sector) і Регіональні Сектори (Regional Sectors) [8].

Нині чисельність RBs становить 12, основним завданням яких $є$ охорона громадського порядку у взаємодії з поліцією штатів, у яких вони дислокуються, та надання допомоги основним силам CISF при вирішенні раптово виникаючих завдань [8].

FSW було сформовано у квітні 1970 р. та сьогодні є найбільшим постачальником послуг із протипожежного захисту об'єктів серед всіх пожежних служб Індії. Чисельність особового складу FSW складає 7549 пожежників. FSW забезпечує пожежну охорону 102 об'єктів KI нафтохімічного, металургійного, космічного, енергетичного, оборонного та ін. комплексів, надає консалтингові послуги організаціям різних форм власності з протипожежного захисту об'єктів [8; 10, с. 134].

У 2006 р. у складі CISF була створена SSG, основною функцією якої є забезпечення фізичного захисту осіб, перелік яких визначається Міністерством внутрішніх справ, i, за необхідності, проведення ї евакуації [9]. Станом на грудень 2017 р. персонал SSG налічував 1200 осіб, які забезпечували фізичний захист 77 охоронюваних персон [11].

Із 2008 р. до складу CISF входить UN FPU. UN FPU із серпня 2008 р. і дотепер виконує різноманітні завдання у складі місій Організації Об'єднаних Націй на Гаїті, а саме: забезпечує безпеку резиденції Президента Гаїті, надає допомогу місцевій поліції, бере участь у проведенні гуманітарних акцій тощо. Чисельність UN FPU дорівнює близько 140 особам [10, с. 134].

Сектор підготовки складається 3 Національної Академії Промислової Безпеки (National Industrial Security Academy, далі NISA) та шістьох Рекрутингових Центрів Підготовки (Recruit Training Centers, далі RTCs). У свою чергу, до складу NISA входить Інститут підготовки фахівців пожежної охорони (Fire Service Training Institute, далі - FSTI) [8].

NISA була створена у грудні 1990 р. на базі Коледжу підготовки фахівців для CISF. NISA здійснює підготовки офіцерів для потреб CISF, інших формувань CAPF і Поліції Штатів [12].

FSTI є головним навчальним закладом із пожежної охоронив країні. УFSTIпроходятьпідготовку майбутні фахівці з протипожежної безпеки не лише CISF, а й Національної Пожежної Служби, Берегової Охорони тощо [12].

y RTCs здійснюється підготовка спеціалістів для підрозділів CISF за всіма напрямами діяльності формування.

У 1999 р. сталося викрадення літака Індійських Авіаліній рейсу № IC-814 Катманду Делі. Саме після цього випадку керівництвом Індії було прийнято рішення про створення у складі CISF Польових Підрозділів з охорони аеропортів (Field Formation Units, далі - FFUs). З 2000 р. вказані підрозділи почали виконання покладених на них функцій. Нині сили FFUs забезпечують безпеку у 59 аеропортах по всій території держави [10, с. 134].

Також до складу CISF входять вісім Регіональних Секторів, зони відповідальності яких розподілені за адміністративно-територіальним принципом, а саме: Північний (North), 


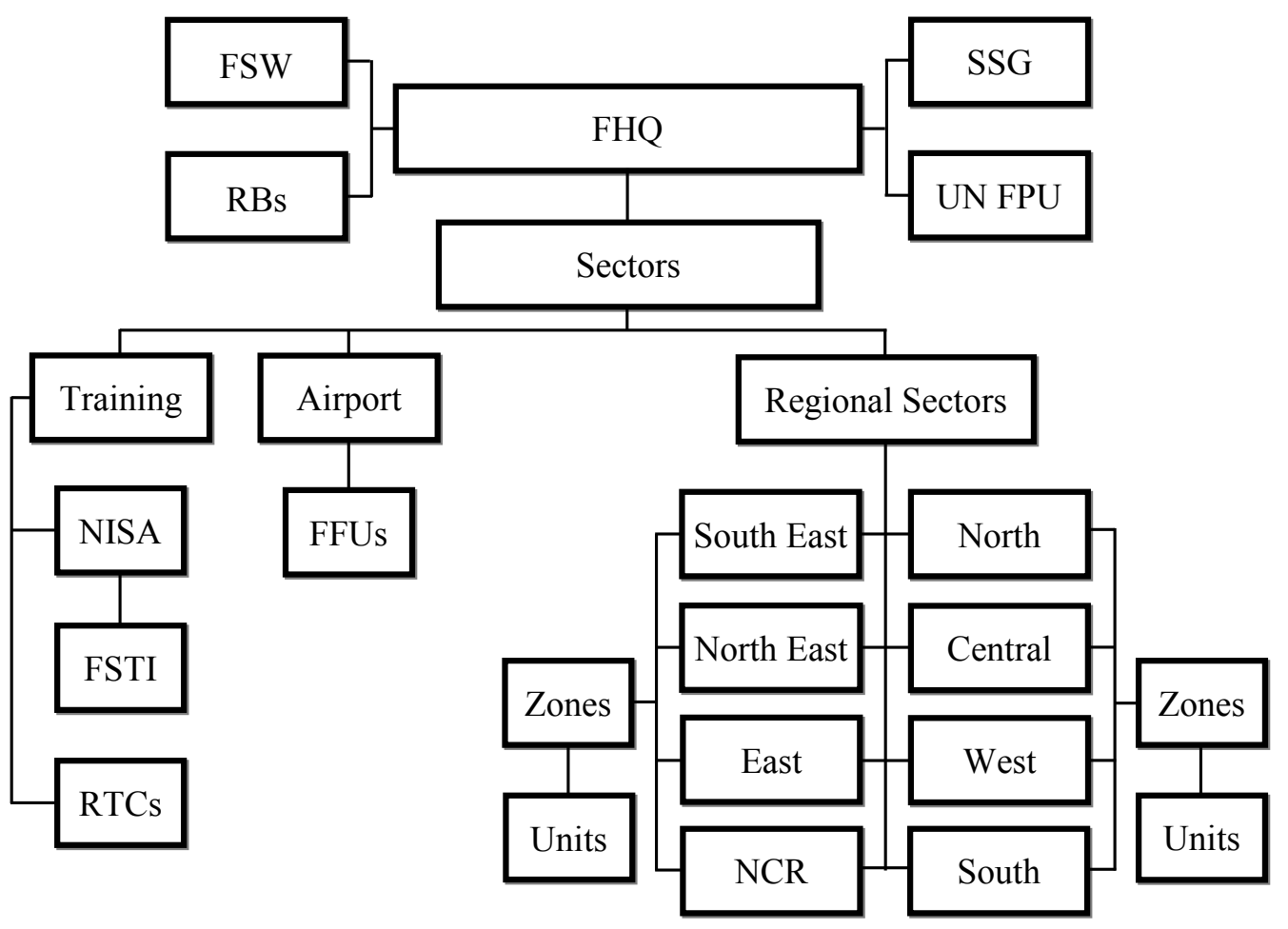

Pис. 1. Загальна структура CISF

Джерело: розроблено авторами за даними [8]

Південно-східний (South East), Центральний (Central), Північно-східний (North East), Західний (West), Східний (East), Південний (South) i Національний Столичний (National Capital Region, далі - NCR). У свою чергу, кожен Регіональний Сектор поділений на зони, в яких здійснюють діяльність відповідні підрозділи [8].

Сьогодні підрозділи зазначених Регіональних Секторів здійснюють охорону близько 280 об'єктів KI різних форм власності, серед яких атомні електричні станції, теплові та гідроелектростанції, нафтові родовища, нафтопереробні заводи, підприємства оборонно-промислового комплексу та космічної галузі, морські порти, урядові будівлі, об'єкти культурної спадщини національного значення тощо [10, с. 133].

Крім того, на підрозділи CISF покладена функція 3 охорони монетних дворів Індії, що входять до складу Державної Індійської Корпорації (The Security Printing and Minting Corporation of India Limited), а також грошових цінностей під час їх перевезення.

Також із квітня 2007 р. близько 7100 представників CISF виконують завдання з охорони 159 станцій метрополітену м. Делі [10, с. 134].

На рис. 1 наведена загальна організаційно-штатна структура CISF.
Висновки. Отже, у статті проведене дослідження особливостей призначення, основних функцій, організаційно-штатної структури та досвіду діяльності CISF.

Результати проведеного дослідження дозволяють стверджувати, що порівняно з НГУ під охороною CISF перебуває значно більша кількість об'єктів KI. Крім того, CISF здійснює охорону категорій об'єктів, які НГУ за звичайних умов не охороняє, наприклад: морські порти, аеропорти, об'єкти культурної спадщини національного значення тощо. До того ж, на відміну від НГУ, підрозділи CISF виконують ряд специфічних функцій, не притаманних НГУ, а саме: пожежну охорону об'єктів, що охороняються; забезпечення безпеки посадових осіб, щодо яких здійснюється державна охорона, та ін.

Отримані результати дослідження можуть використовуватися органами військового управління 3 метою проведення аналізу на предмет можливості впровадження зазначених особливостей у діяльність НГУ.

Напрямом подальшої роботи може бути проведення дослідження особливостей призначення, основних функцій, організаційно-штатної структури та досвіду діяльності суб'єктів захисту об'єктів КІ в інших провідних державах світу. 


\section{ЛIТЕРАТУРА:}

1. Євсєєв В.О. Можливі шляхи удосконалення захисту критичної інфрраструктури України з урахуванням світового досвіду. Збірник наукових праць Харківського національного університету Повітряних Сил. 2016. № 4 (49). С. 168-172.

2. Павлов Д.М. Забезпечення фрізичної безпеки ядерних об'єктів в Україні в умовах зростання військово-терористичної загрози: організаційно-правовий аспект. Юридична наука. 2015. № 3. С. 21-27.

3. Про Національну гвардію України : Закон України від 13 березня 2014 р. № 867-VII. URL: http://zakon.rada.gov.ua/laws/show/867-18 (дата звернення: 22.12.2019).

4. Євсєєв В.О., Тробюк Д.В. Охорона ядерних установок і матеріалів не військового призначення. Досвід Великобританії. Вчені записки Таврійського національного університету імені В.І. Вернадського. Серія: Державне управління. 2019. Т. 30 (69). № 1. C. $146-150$.

5. Суходоля О.М. Захист критичної інсрраструктури в умовах гібридної війни: проблеми та пріори- тети держаної політики України. Стратегічні пріориmemu. 2016. № 3 (40). С. 62-76.

6. Ходатенко Е.Н. Гражданская полиция Индии, ее организация и управление. Вестник Московского университета МВД России. 2009. № 11. С. 142-144.

7. Central Armed Police Forces. URL: http://capf.gov. in/ (дата звернення: 23.12.2019).

8. Central Industrial Security Forces. URL: https://www.cisf.gov.in/ (дата звернення: 23.12.2019).

9. Central Industrial Security Forces. URL: https://en.wikipedia.org/wiki/Central_Industrial_ Security_Force (дата звернення: 24.12.2019).

10. Annual Report of Ministry of Home Affairs 2017-18. P. 133-134. URL: https://mha.gov.in/ sites/default/files/MINISTRY\%200F\%20HOME\%20 AFFAIR\%20AR\%202017-18\%20FOR\%20WEB.pdf (дата звернення: 24.12.2019).

11. CISF readies SSG unit for VIP security. URL: http://www.uniindia.com/news/india/cisf-readies-ssgunit-for-vip-security/1071200.html (дата звернення: 26.12.2019).

12. National Industrial Security Academy. URL: http://nisa.ap.nic.in/index.htm (дата звернення: 26.12.2019). 